$14^{\text {th }}$ Conf. Agric. Develop. Res., Fac. of Agric., Ain Shams Univ., March, 2019., Cairo, Egypt

Special Issue, 27(1), 529 - 537, 2019

Website: http://strategy-plan.asu.edu.eg/AUJASCI/

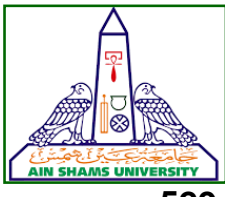

\title{
DETECTION FOR MECA GENE IN EGYPTIAN CLINICAL Staphylococcus aureus SAMPLES AND STUDY THEIR GENOTOXIC ACTIVITY
}

\author{
Marwa Hassan, Ibrahim S.A., Abdel Razek A.B., Sawsan Y. Elateek \\ Genetic Dept., Fac. of Agric., Ain Shams Univ., P.O. Box 68, Hadyek Shoubra 11241, \\ Cairo, Egypt
}

$[49$

${ }^{*}$ Corresponding author: selateek@agr.asu.edu.eg

Received 25 February, 2019, $\quad$ Accepted 10 March, 2019

\begin{abstract}
Staphylococcus aureus isolates were isolated from fifty clinical samples collected from Ain Shams University Hospitals (March - July 2016) and identified using biochemical and microbiological tests. PCR was performed using specific primers to determine the isolates of Methicillin - Resistant Staphylococcus aureus (MRSA) based on the presence of mecA gene. Thirty-four isolates from total fifty isolates (68\%) were identified as MRSA isolates. To study the genotoxicity for this isolates, forty-five mice were injected with these MRSA isolates and comet and micronuclei assays were performed on mice liver tissues and bone marrow respectively. These assays revealed $24 \%$ $22 \%$ DNA damage as an indicator for chromosomal breakage by comet and micronucleus assays respectively which indicate that infection with these isolates leads to mutations. Studying these isolate furthermore will give an insight on how critical maintaining high standard hygiene in Egyptian hospitals and attention to infection control system can prevent occur of outbreaks
\end{abstract}

Key words: Staphylococcus aureus, MecA gene, Methicillin-Resistant Staphylococcus aureus (MRSA), Polymerase Chain Reaction (PCR), Comet assay, Micronucleus assay

\section{INTRODUCTION}

Staphylococcus aureus is an important human pathogen that causes wide range of infection in hospitals and societies including superficial infection and systemic infection. $S$. aureus pathogenicity caused by secreted virulence factors such as extracellular proteins group which facilities binding with the host - in our case - the human (Gordon and Lowy, 2008). S. aureus recently became one of the most threatening multi-drug resistant agents, especially in low hygiene hospitals and crowded communities (Cuervo et al 2010). Due to its increased prevalence, it developed more than one strain resistant to different antibiotic classes such as Methicillin-which called (MRSA). Methicillin resistant Staphylococcus aureus (MRSA) is defined by the integrated of a large transposable element called Staphylococcal Cassette Chromosome me$\mathrm{cA}$ (SCCmec) in its genome. That contains the $m e c A$ gene that encoded to an alternative Penicillin Binding Protein, PBP2a, with low binding affinity to $\beta$-lactam antibiotic group (Foster, 2017). MRSA developed resistance against Vancomycin which is always has been used to treatment of MRSA infection, this strain called Vancomycin-Resistance $S$. aureus or VRSA strains (Gradate and Tomasz, 2014). In our study, we focused on MRSA pathogen since its furious spread led to increase in the mortality of the patients in hospitals/communities due to the delay of the diagnosis, treatment of the patients, and also the slower response for treatment from patients with weak immunity system such as diabetic and cancer patients (Priyadharshini et al 2013, Lin et al 2017 and Rozgonyi, 2007). MRSA pathogen behaves differently to protect itself from host immunity system. It secretes molecules to escape from innate human immune system by inhibiting the function of phagocytosis and neutrophils. Furthermore, escaping from complement system that participate in protect human from any invasion which lead to genotoxicity (DNA damage) (McGuinness et al 2016). Surprisely, not many studies focused on the genotoxicity that caused by MRSA pathogen even though, the presence of reliable genetic methods to detect 
the genotoxicity, such as the Comet and micronucleus assay (Karyank et al 2015).

That's why our study was initiated; to work on detecting and identifying Egyptian MRSA isolates in hospitals and recognize the ability of these isolates to damage the DNA through genotoxicity of the patients. So we can shed some light on the expected approach to prevent the spreading of this MRSA pathogen in hospitals.

\section{MATERIALS AND METHODS}

This study was carried out at Ain Shams Center of Genetic Engineering and Biotechnology laboratories (ACGEB) and National Research Center (NRC). Fifty bacterial isolates from various clinical samples including blood, urine, sputum, wounds, pus, ascetic fluid and abscess, were collected from Department of Microbiology, Ain Shams University Hospitals, Cairo, Egypt. Standard S. aureus used in this study identified as $S$. aureus standard strain (ATCC 6538) collected from Cairo Microbiological Resources Centre (Cairo MIRCEN) in Ain Shams University, Faculty of Agriculture - Shobura Egypt.

\section{Bacterial Identification}

All isolates were identified and confirmed as $S$. aureus based on biochemical tests. It were streaked on Baird Parker as a selective medium and incubated at $37^{\circ} \mathrm{C}$ for $24 \mathrm{hrs}$. as well, stained by Gram stain, Catalase and coagulase tests were also performed (Mossel, 1962 and Costa, 2013).

Polymerase chain reaction for the detection of mecA gene in Staphylococcus aureus isolates

Chromosomal DNA was isolated from each $S$. aureus isolates using the DNA isolation kit (Promega, USA), the quality of the chromosomal DNA was evaluated by concentrations were determined using Quantus Fluorometer (Promega, USA) by QuantiFluor ${ }^{\circledR}$ dsDNA System Kit, and normalized to $10 \mathrm{ng} / \mu \mathrm{l}$. PCR was performed on all $S$. aureus isolates using PCR master mix (Promega, USA) to determine the presence of $M e c$ $A$ gene, by specific primer (Geha et al 1994 and Pillai et al 2012). The oligonucleotides sequence of the 25-bp primer pair used as follow: mecAl F: 5' GTAGAAATGACTGAACGTCCGATAA-3` 342) and mecA2 $\mathrm{R}$ : 5'CCAATTCCACATTGTTTCGGTCTAA-3) $627)$ which produce 310 bp PCR products. The components of each PCR $25 \mu$ reaction: PCR Master Mix, $12.5 \mu \mathrm{l}$; each primer $1 \mu \mathrm{M}$; template DNA (3.6-9.8) $\mu \mathrm{l}$ according to DNA concentration for each sample, complete with water nuclease-free up to $25 \mu \mathrm{l}$ as total volume. PCR program included 30 cycle of pre-denaturation at $94^{\circ} \mathrm{C}$ for $4 \mathrm{~min}$. followed by denaturation at $94^{\circ} \mathrm{C}$ for $45 \mathrm{sec}$., annealing at $55^{\circ} \mathrm{C}$ for $45 \mathrm{sec}$., extension at $72^{\circ} \mathrm{C}$ for 1 $\mathrm{min}$., and final extension for $5 \mathrm{~min}$.

\section{Genotoxicity assay}

This part from the study was approved by the Ethical Committee of Animal Research (ECAR) at National Research Center (NRC). Forty five albino males' mice were used, six weeks of age, weighing approximately $25 \mathrm{~g}$, divided into nine groups, each group had five animals as replicates, and were injected interproteneal by different types of samples from wound, sputum, ascetic fluid, urine, blood, pus isolates and MSSA strain as a negative control.

\section{Preparation of bacterial inoculums for mice injection}

The colonies were grown on Trypticase Soy Broth (TSB) medium (Silva-Santana et al 2016) for $24 \mathrm{hrs}$. to acquire the dilution of $1 * 106 \mathrm{CFU} / \mathrm{ml}$, using tubes containing serial dilutions in sterile saline $(0.9 \% \mathrm{NaCl})$. The Animals were injected with $100 \mu$ of bacterial suspension, except the control group, which were injected with $100 \mu$ sterile saline $(0.9 \% \mathrm{NaCl})$ only. Mice were sacrificed $48 \mathrm{hrs}$. after injection and liver tissue was taken for comet assay and bone marrow was taken for micronucleus assay.

\section{Comet assay}

Liver tissues were digested in trypsin to produce a single cell suspension; cells were placed on a microscope slide coated with agarose gel. The slide was then placed in solution containing $0.5 \%$ SDS, $30 \mathrm{mM}$ EDTA, $\mathrm{p}^{\mathrm{H}} 8.0$ at $50^{\circ} \mathrm{C}$ for $4 \mathrm{hrs}$. then the slides were left overnight at room temperature in Tris/Borate/EDTA buffer, $\mathrm{p}^{\mathrm{H}}$ 8.0. Samples were electrophoresed for $25 \mathrm{~min}$. at $0.6 \mathrm{v} / \mathrm{cm}$, and then stained with Ethidium Bromide. Images by fluorescent microscope with a CCD camera were taken and count the cells which took the comet shape to determine the percentage of cells with DNA damage in 100 cells for each sample. (Olive et al 1990, Maynou et al 2014 and Collins et al 1997). 


\section{Micronucleus assay}

The bone marrow cells were left in small volume of fetal calf serum for slide preparation and fixation by methyl alcohol and stained by $5 \%$ Giemsa stain for $10 \mathrm{~min}$., prepare three slide for the same animal, under microscope and search on the percentage of Micronucleated PolyChromatic Erythrocytes (\%MnPCEs) Between 2,000 polychromatic erythrocytes (PCEs) under oily lens (Adler, 1984 and Alad, 2009).

\section{Statistical analysis}

Statistical analysis was performed using SPSS software program (10.0) (1998 - by SAS Institute Inc., Cary, NC., USA), The PCR results were statistically analyzed by Chi-square analysis as well as calculated variables as percentage followed by ANOVA one way analysis. As for the comet and micronucleus assay parameters, the critical level for rejection of the null hypothesis was considered as less than $5 \%$ is significant and more than $5 \%$ non-significant.

\section{RESULTS AND DISCUSSION}

Fifty isolates were collected from males and females equally, different ages including infants and adults, also from different clinical samples (urine, abscess, blood, pus, wound, sputum and ascetic fluid).

Identification of the isolates was performed using biochemical tests. All isolates were cultured on Baird Parker medium as selective media for $S$. aureus giving black and shiny colonies as shows in Fig. 1, staining with Gram stain and all isolates gave Gram positive results as shows in Fig. 2, also, Catalase test was performed to all isolates which gave Catalase positive results as shows in Fig. 3. All isolates were confirmed to be Staphylococcus.

Besides, as the pie chart in Fig. 4 shows the percentages of Staphylococcus presence in different types of the clinical samples collected from the hospital. Out of 50 samples, $35 \%$ were wound samples, $29 \%$ were blood samples, $14 \%$ were pus samples, $10 \%$ were sputum samples, $6 \%$ were abscess samples, $4 \%$ were urine samples, and $2 \%$ were from ascetic fluids.

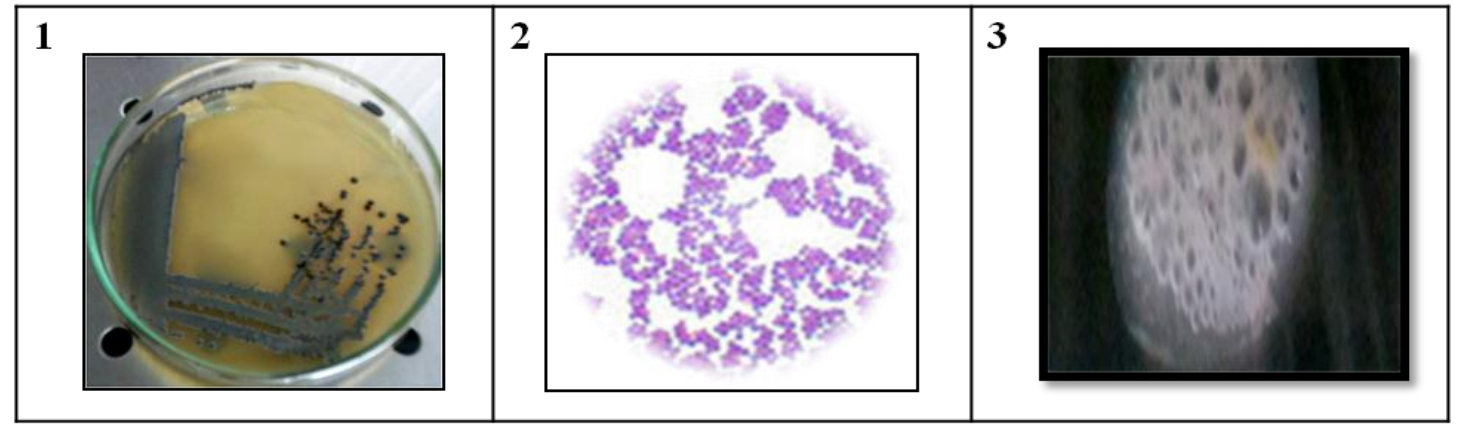

Fig. 1. S. aureus growth on Baird

Fig. 2. S. aureus Gram stain +

Fig. 3. S. aureus Catalase + Parker medium

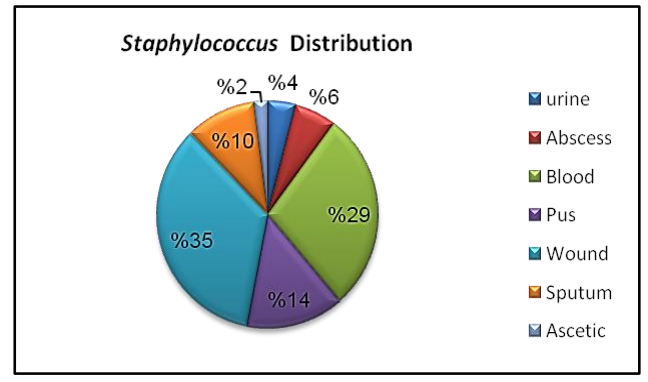

Fig. 4. Distribution of \% Staphylococcus isolates from different clinical samples
Furthermore, the detection of MRSA isolates prevalence in the fifty isolates from the clinical samples was performed using PCR specific primer for mecA gene with product size of $310 \mathrm{bp}$. MRSA isolates represented 34 isolates from the total isolates while the MSSA isolates represented the latter of the isolates as shown in Fig. 5. 


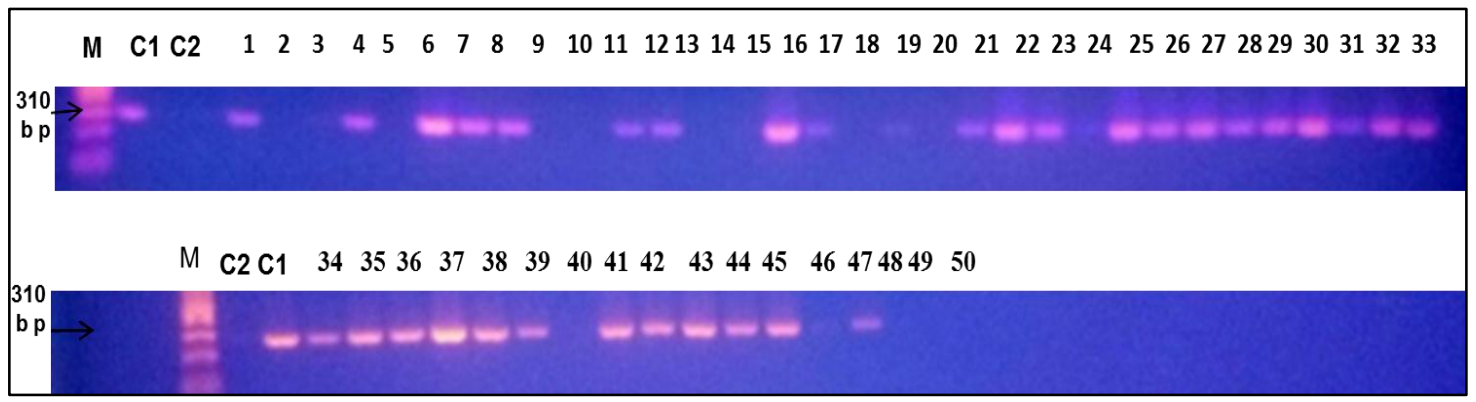

Fig. 5. MecA gene detection within the Staphylococcus isolates from clinical samples; C1: S. aureus ATCC 6538 (MSSA strain- negative control); C2: S. aureus (MRSA strain- positive control); and M: 100bp DNA ladder

As shown in Table 1, PCR results recorded MRSA isolates were represented by $68 \%$, whereas MSSA isolates were represented $32 \%$. There was significant difference between MRSA and MSSA prevalence $(p<0.05)$.

Table 1. Distribution of MRSA/MSSA isolates from different types of samples detected by PCR

\begin{tabular}{|c|c|c|c|c|}
\hline \multirow{2}{*}{ Type of Sample } & \multicolumn{2}{|c|}{ MSSA Isolates } & \multicolumn{2}{c|}{ MRSA Isolates } \\
\cline { 2 - 5 } & $\begin{array}{c}\text { Number/ } \\
\text { Total }\end{array}$ & $\%$ & $\begin{array}{c}\text { Num- } \\
\text { ber/Total }\end{array}$ & $\%$ \\
\hline Blood & $6 / 50$ & $10 \%$ & $8 / 50$ & $18 \%$ \\
Pus & $1 / 50$ & $2 \%$ & $6 / 50$ & $12 \%$ \\
Urine & - & -- & $2 / 50$ & $4 \%$ \\
Sputum & $1 / 50$ & $2 \%$ & $4 / 50$ & $8 \%$ \\
Ascetic Fluid & - & -- & $1 / 50$ & $2 \%$ \\
Abscess & $1 / 50$ & $2 \%$ & $2 / 50$ & $4 \%$ \\
Wound & $6 / 50$ & $12 \%$ & $11 / 50$ & $20 \%$ \\
S. aureus Reference & $1 / 50$ & $2 \%$ & - & - \\
Strain & & & & \\
\hline
\end{tabular}

After MRSA isolates were detected, each group of mice was injected with different type of samples from these isolates (Table 2). Tissues from bone marrow and liver samples were collected from mice, and a significant change was observed in the shape and color of the liver as shown in Figure 6. Infected liver samples were used in the comet assay and bone marrow samples were used in micronucleus assay.

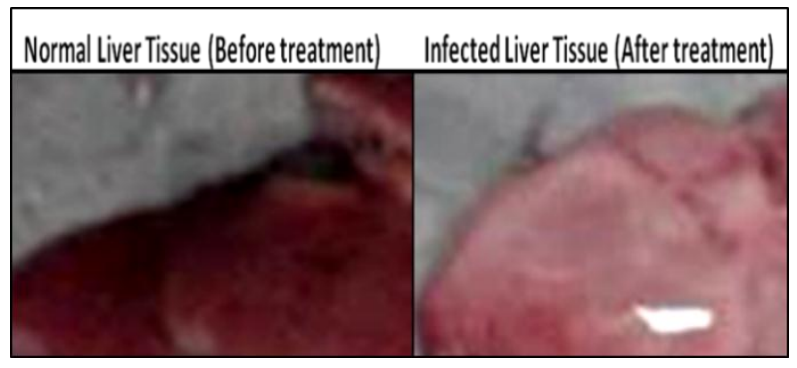

Fig. 6.Comparison between normal liver tissue and infected liver tissue with MRSA isolate

As for the Comet assay as a genotoxicity assay, visual damage in the DNA caused by the MRSA infection was noticed and documented as shown in (Figure 7). It showed three different levels of damage (class1, 2 and 3 ) in DNA in all infected mice liver compared to the healthy ones (class 0).

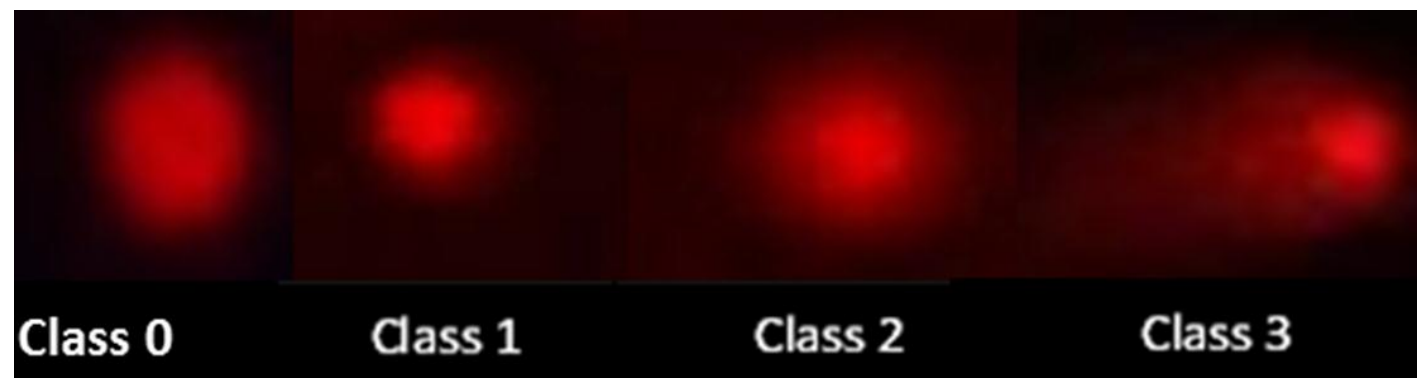

Fig. 7. Classification of fluorescent images of the Comet assay: Normal nucleus (class 0), gradual increase in the comet tail (class 1), with a decrease in the nuclear DNA content (class 2 and class 3 ) 
Also, 500 cells from each mouse were investigated and classified according to type of class of damage (class 1, 2 and 3 ) and this visual damage of DNA was scored as shown in Table 2.

There were significant differences between DNA damage that occurred in MRSA isolates from pus, wound, ascetic fluid, urine, blood and sputum samples compared to no DNA damage in MSSA strain (ATCC 6538) as a negative control. Furthermore, the mean of the percentage of DNA damage in comet tail which occur in all MRSA isolates, was calculated and compared to the percentage of no DNA damage in comet tail of all control groups as shown in Table 3.

Table 2. Visual score of DNA damage in mice liver tissues treated with MRSA isolates collected from the clinical samples (mean \pm SD)

\begin{tabular}{|c|c|c|c|c|c|c|c|c|}
\hline \multirow[b]{2}{*}{ Treatment } & \multicolumn{2}{|c|}{ No. of cells } & \multicolumn{4}{|c|}{ Class } & \multirow[b]{2}{*}{ SD } & \multirow{2}{*}{$\begin{array}{c}\text { DNA damaged } \\
\text { cells } \% \\
\text { (Mean } \pm \text { SEM) }\end{array}$} \\
\hline & Analyzed ${ }^{*}$ & Comets & 0 & 1 & 2 & 3 & & \\
\hline Saline (- control) & 500 & 26 & 474 & 21 & 5 & 0 & 0.75 & $5.2 \pm 0.75^{d}$ \\
\hline MRSA (+ control) & 500 & 152 & 348 & 41 & 52 & 59 & 1.62 & $30.4 \pm 1.62^{\mathrm{a}}$ \\
\hline MRSA from Sputum & 500 & 91 & 409 & 33 & 35 & 23 & 1.47 & $18.2 \pm 1.47^{c}$ \\
\hline MRSA from Wound & 500 & 113 & 387 & 34 & 41 & 38 & 1.50 & $22.6 \pm 1.50^{b}$ \\
\hline MRSA from Ascetic fluid & 500 & 103 & 397 & 40 & 29 & 34 & 1.50 & $20.6 \pm 1.49^{\mathrm{bc}}$ \\
\hline MRSA from Urine & 500 & 85 & 415 & 26 & 32 & 27 & 1.41 & $17.0 \pm 1.41^{\mathrm{c}}$ \\
\hline MRSA from Blood & 500 & 107 & 393 & 35 & 33 & 39 & 0.80 & $21.4 \pm 0.80^{\mathrm{bc}}$ \\
\hline MRSA from Pus & 500 & 116 & 384 & 39 & 41 & 36 & 1.47 & $23.2 \pm 1.47^{b}$ \\
\hline MSSA (- control) & 500 & 98 & 402 & 31 & 38 & 29 & 1.02 & $19.6 \pm 1.01^{c}$ \\
\hline
\end{tabular}

a,b,c,d, represented significant difference between groups

Table 3. Comet parameters for analyzed 500 cells from each mouse's liver (Mean \pm SEM)

\begin{tabular}{|c|c|c|c|}
\hline $\begin{array}{c}\text { Comet pa- } \\
\text { rameters }\end{array}$ & $\begin{array}{c}\text { Mice injected } \\
\text { with MRSA } \\
\text { strain }(\mathrm{n}=35) \\
(\text { Mean } \pm \text { SEM) }\end{array}$ & $\begin{array}{c}\text { Mice injected } \\
\text { with MSSA strain } \\
(\mathbf{n}=5) \\
(\text { Mean } \pm \text { SEM) }\end{array}$ & $\begin{array}{c}\text { Controls } \\
(\mathbf{n}=5) \\
(\text { Mean } \pm S E M)\end{array}$ \\
\hline $\begin{array}{c}\text { Percentage of } \\
\text { DNA damage } \\
\text { in comet tail }\end{array}$ & $23.76 \pm 1.525$ & $19.6 \pm 1.01$ & $5.2 \pm 0.75$ \\
\hline $\begin{array}{c}\text { Percentage of } \\
\text { DNA damage } \\
\text { in comet head }\end{array}$ & $76.24 \pm 1.525$ & $80.4 \pm 1.01$ & $94.8 \pm 0.75$ \\
\hline
\end{tabular}

\section{SEM: standard error}

Subsequent to the comet assay, micronucleus assay, as a confirmation assay, was performed by screening 2000 polychromatic erythrocytes cells with three replicates in all bone marrow cells (Figure 8). The mean of Micronuclei (Mn) in PolyChromatic Erythrocytes (PCE) from MRSA-infected bone marrow cells was calculated and found statistically significant in all treated groups compared to non-treated groups - NormoChromatic Erythrocytes (NCE) as negative controls as shown in Table 4 .

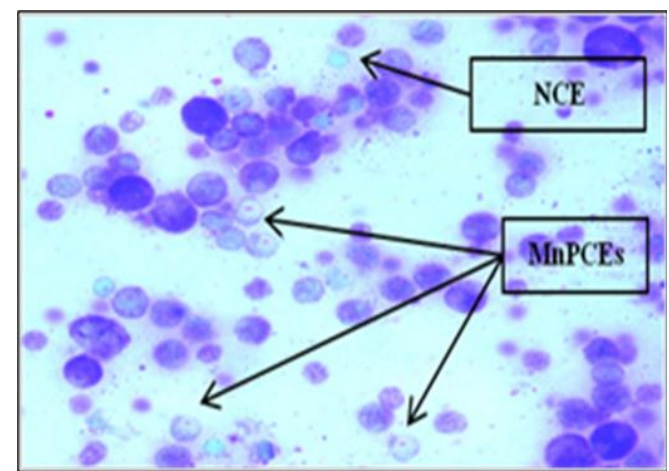

Fig. 8. Bone marrow cells under light microscope untreated - NormoChromatic Erythrocytes (NCEs) and MRSA-treated - Micronucleated PolyChromatic Erythrocytes (MnPCEs) 
Table 4. The treatments of mice with different MRSA and control samples and MnPCEs and NCEs in bone marrow cells (mean $\pm \mathrm{SD}$ ).

\begin{tabular}{|c|c|c|c|c|c|c|c|c|}
\hline \multirow{2}{*}{ Treatment $(\mathrm{mg} / \mathrm{kg})$} & \multirow{2}{*}{$\begin{array}{c}\text { PCE } \\
\text { screened }\end{array}$} & \multicolumn{3}{|c|}{ MnPCEs/2000 PCE } & \multicolumn{2}{|c|}{ NCE } & \multicolumn{2}{|c|}{ PCE/NCE } \\
\hline & & Number & Mean & SD & screened & Ratio & Mean & SD \\
\hline \multirow{3}{*}{ Saline (- control) } & 2000 & 7 & \multirow{3}{*}{6.33} & \multirow{3}{*}{1.15} & 743 & 2.69 & \multirow{3}{*}{2.71} & \multirow{3}{*}{0.05} \\
\hline & 2000 & 5 & & & 752 & 2.66 & & \\
\hline & 2000 & 7 & & & 723 & 2.77 & & \\
\hline \multirow{3}{*}{ MRSA (+ control) } & 2000 & 33 & \multirow{3}{*}{29.33} & \multirow{3}{*}{3.51} & 542 & 3.69 & \multirow{3}{*}{3.42} & \multirow{3}{*}{0.24} \\
\hline & 2000 & 26 & & & 598 & 3.34 & & \\
\hline & 2000 & 29 & & & 619 & 3.23 & & \\
\hline \multirow{3}{*}{$\begin{array}{c}\text { MRSA } \\
\text { from Sputum }\end{array}$} & 2000 & 21 & \multirow{3}{*}{19.67} & \multirow{3}{*}{1.15} & 663 & 3.02 & \multirow{3}{*}{3.15} & \multirow{3}{*}{0.11} \\
\hline & 2000 & 19 & & & 621 & 3.22 & & \\
\hline & 2000 & 19 & & & 623 & 3.21 & & \\
\hline \multirow{3}{*}{$\begin{array}{c}\text { MRSA } \\
\text { from Wound }\end{array}$} & 2000 & 25 & \multirow{3}{*}{23.33} & \multirow{3}{*}{1.53} & 573 & 3.49 & \multirow{3}{*}{3.31} & \multirow{3}{*}{0.24} \\
\hline & 2000 & 23 & & & 588 & 3.40 & & \\
\hline & 2000 & 22 & & & 657 & 3.04 & & \\
\hline \multirow{3}{*}{$\begin{array}{c}\text { MRSA } \\
\text { from } \\
\text { Ascetic Fluid }\end{array}$} & 2000 & 23 & \multirow{3}{*}{21.67} & \multirow{3}{*}{1.15} & 673 & 2.97 & \multirow{3}{*}{3.01} & \multirow{3}{*}{0.36} \\
\hline & 2000 & 21 & & & 750 & 2.67 & & \\
\hline & 2000 & 21 & & & 591 & 3.38 & & \\
\hline & 2000 & 18 & & & 688 & 2.91 & & \\
\hline MRSA from Urine & 2000 & 19 & 18.67 & 0.58 & 649 & 3.08 & 2.96 & 0.11 \\
\hline & 2000 & 19 & & & 695 & 2.88 & & \\
\hline & 2000 & 23 & & & 643 & 3.11 & & \\
\hline MRSA from Blood & 2000 & 24 & 22.67 & 1.53 & 649 & 3.08 & 3.20 & 0.17 \\
\hline & 2000 & 21 & & & 589 & 3.40 & & \\
\hline & 2000 & 25 & & & 681 & 2.94 & & \\
\hline MRSA from Pus & 2000 & 26 & 24.67 & 1.53 & 611 & 3.27 & 3.23 & 0.27 \\
\hline & 2000 & 23 & & & 577 & 3.47 & & \\
\hline & 2000 & 23 & & & 633 & 3.16 & & \\
\hline (VISSA & 2000 & 20 & 20.67 & 2.08 & 654 & 3.06 & 3.12 & 0.05 \\
\hline & 2000 & 19 & & & 639 & 3.13 & & \\
\hline
\end{tabular}

\section{DISCUSSION}

In recent years and due to low hygiene in hospitals, MRSA strains became widely spread in Egypt. There were several studies documented the appearance of MRSA strains in hospitals through Egypt. In our study and out of 50 isolates, $68 \%$ of them were MRSA isolates which were found between patients in Ain Shams University Hospital. In similar study carried out by Hefzy and Hassan (2016) out of $70 \mathrm{~S}$. aureus isolates collected from
Fayoum University Hospital, $57 \%$ of them were MRSA isolates, while in Mansoura University Hospital and out of $70 \mathrm{~S}$. aureus isolates collected, there were $40 \%$ of these isolates represented MRSA (Elshabrawy et al 2017). Each study has been done in Egypt focused on the detection of $\operatorname{mec} A$ gene and finding the perfect matched primer pairs that cover big portion of the gene, which known for its responsibility of inducing resistant for $\beta$-lactam group triggering different symptoms of MRSA infection in hospitalized patients. So for 
Hefzy and Hassan (2016), they used duplex PCR to identify $\operatorname{mec} A$ gene, but in Elshabrawy et al 2017, they used primers to search for the whole cassette of mecA gene (SCCmec). In our study, we used a very specific primer that has been used in Pillai et al 2012, which was able to detect $37 \%$ MRSA isolates from 165 samples collected from different hospitals in India. The same primer pairs was used by Sahebnasagh et al $\mathbf{2 0 1 4}$ in Iran to successfully identify 69\% MRSA isolates from 100 samples. All these primer pairs were actually designed and adjusted to pick mecA gene through multiplex PCR which was done by Geha et al 1994 who successes to detect $17 \%$ MRSA isolates from 228 samples collected from different states in U.S.

Furthermore and due to the increase in lethality of MRSA pathogen around the world between adults, it was actually causing more death cases in neonates especially in the United States (Gordon and Lowy 2008). That is why our study on MRSA pathogen focused on detecting genotoxicity in the hospitalized patients. We found that using comet assay is considered the most reliable assay to detect the genotoxicity through capturing the DNA damage caused by MRSA pathogen even though not previous studies on comet assay were performed before in Egypt. Comet assay was performed in our study on different samples of MRSA isolates and the result showed significant differences before and after the treatment that caused genotoxicity. Three classes of damage were seen under the fluorescent microscope, class 1 was presented by simple DNA damage, class 2 was represented by moderate DNA damage, and class 3 was represented by severe DNA damage. But in other countries such as in India, Priyadharshini et al 2013, MRSA isolates led to septicemia in the neonates which urged the detection of genotoxicity through using comet assay and it confirmed the three different classes of DNA damage.

In addition to comet assay, micronucleus assay was performed to confirm comet assay results. There were significant differences in DNA damage between control groups and all mice groups which were injected with MRSA isolates. This indicated the ability of MRSA isolates to cause mutagenicity (Priyad harshini, et al 2013 and El-Gendy et al 2017). A similar study in Egypt was performed by El-Gendy et al (2017) using rats as model organism and injected it with six different MRSA isolates. These isolates were isolated from patients with cancer and the micronucleus assay was performed. Micronucleated cells were calculated and evaluated and the results were similar to our re- sults which indicate the severe damage that MRSA pathogen can cause.

mecA gene is a marker for MRSA strains detection by PCR, MRSA strain became more virulent strain around the world and keep increasing in prevalent, and after use many reliable genetic methods such as comet and micronucleus assay, we can say that $S$.aureus has ability to induce genetic toxicity in hospitalized patients

\section{REFERENCES}

Adler I.D., Venitt S., Parry J.M., Aquardo C.F. and Noom W.A. 1984. Cytogenetic tests in mammals. In: Mutagenicity testing (a practical approach). IRI Press, Oxford, pp. 275-306.

Alad, P.A.O., Cocos A. A.S., Balolong E.C., Parungao M.M. and Marfori E.C. 2009. Mutagenicity potential of the novel drug Trichosetin estimated by using the rec assay and Micronucleus test. Philippine J. of science, 138 (2), 119-124.

Collins, A., Dusinska M., Franklin M., Somorovska M., Petrovska H., Duthie S., Fillion L., Panayiotidis, M., Raslova K. and Vaughan N. 1997. Comet assay in human biomonitoring studies: Reliability, validation, and applications. Environ. Mol. Mutagen, 30, 139-146.

Costa, A.R. 2013. Staphylococcus aureus virulence factors and disease Microbiology pathogens and strategies for combating them, Science Technology and Education Book, 1, 702-710.

Cuervo, S.I., Corte J.A., Sanchez R., Guez J.Y.R., Silva E. and Tibavizco D. and Arroyo P. 2010. Risk factors for mortality caused by Staphylococcus aureus bacteremia in cancer patients. Enferm. Infec. Microbial. Clin., 28(6), 349 - 354.

El-Gendy, M.M.A.A., Abdel-Wahhab, K.G., Mannaa F.A., Farghaly A.A. and El-Bondkly A.M.A. 2017. Carcinogenic Activities and Sperm Abnormalities of Methicillin Resistance Staphylococcus aureus and Inhibition of Their Virulence Potentials by Ayamycin. Appl. Biochem. Biotechnol. 183(3), 833-852.

Elshabrawy, W.O., Zaki M.E. and Kamal M.F. 2017. Genetic and phenotypic study of Methicillin - resistant Staphylococcus aureus among patient and health care workers in Mansoura University Hospital Egypt. Iranian J. of Microbiology, 9 (2), 82-88.

Foster, T. J. 2017. Antibiotic resistance in Staphylococcus aureus. Current status and future pro- 
spects. Microbiology Reviews Book, 41, 430449.

Gardete, S. and Tomasz A. 2014. Mechanisms of vancomycin resistance in Staphylococcus aureus. J. Clinical Investigation, 124(7), 28362840.

Geha, D.J., Uhl, J.R., Gustaferro C.A. and Persing D.H. 1994. Multiplex PCR for the identification of methicillin-resistant Staphylococci in the clinical laboratory. J. Clin. Microbiol., 32, 1768-1772.

Gorden, J. R. and Lowy F. D. 2008. Pathogenesis of Methicillin Resistant Staphylococcus aureus infection. Clinical Infection Disease J., 46, 350-359.

Hefzy, E. M. and Hassan G.M. 2016. Rapid molecular identification of hospital acquired Methicillin resistance staphylococcus aureus (HAMRSA) Lineages. Egyptian J. of Microbiology. 2 (4), 91-97.

Kraynak A.R., Barnum J.E., Cunningham C.L., Ng. A., Ykoruk B.A., Bennet B., Stoffregen D., Merschman M., Freeland E. and Galloway S.M. 2015. Alkaline comet assay in liver and stomach, and micronucleus assay in bone marrow from rats treated with 2- actylaminofluorene, isobutyraldhyde. Genetic toxicology and Environmental Mutagenesis, 786, 7786.

Lin, J., Xu P., Peng Y., Lin D., Ou Q., Zhang T., C. Bai, Ye X., Zhou J. and Yao Z. 2017. Prevalence and characteristics of Staphylococcus aureus and MRSA nasal colonization among community based diabetes in population Foshan China. J. Diabetes Investigation, 8 (3), 382-391.

Maynou, J.R., Gaweka J.E., Bene J. and Ward W.S. 2014. Double - stranded DNA breaks hidden in the neutral comet assay suggest a role of the sperm nuclear matrix in DNA integrity maintenance. Molecular Human Reproduction J., 20 (4), 330-340.

Mcguinness, W. A., Kobayashi S.D. and DeLeo F.R. 2016. Evasion of Neutrophil killing by Staphylococcus aureus. Pathogens, 5(1), 113.

Mossel, D.A.A. 1962. Attempt in classification of catalase positive Staphylococci and micrococci. Journal of Bacteriology, 84, 1140-1147.

Olive, P.L., Banath J.P. and Durand R. E. 1990. Heterogeneity in radiation- induced DNA damage and repair in tumor and normal cells measured using the comet assay. Radiat. Res. 122(1), 86-94

Pillai, M.M., Lethal R. and Sarkar G. 2012. Detection of Methicillin Resistance in Staphylococcus Aureus by Polymerase Chain Reaction and Conventional Methods: A Comparative Study. J. of Laboratory Physicians, 4(2), 83-88.

Priyadharshini, N.A., Chand P., Vishnu Bhat B. and Ramachandra K. Rao 2013. Assessment of DNA damage in term neonates with sepsis by comet assay. Curr. Pediatr. Res., 18 (1), 15-17.

Rozgonyi, F., Kocsis E., Kristóf K. and Nagy K. 2007. Is MRSA more virulent than MSSA? Clinical of Microbiology and Infection, 13, 843-845

Silva-Santana G., Lenzi-Almeida K.C., Fernandes-Santos C., Couto D.S., Paes-DeAlmeida E.C. and Aguiar-Alves F. 2016. Mice Infection by Methicillin-Resistant Staphylococcus aureus from Different Colonization Sites in Humans. Clinical Experimental Pathology J., 6 (1), 2661-2681. 


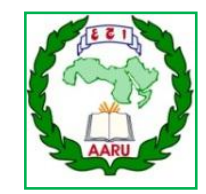

المؤتمر الرابع عشر لبحوث التنمية الزراعية،

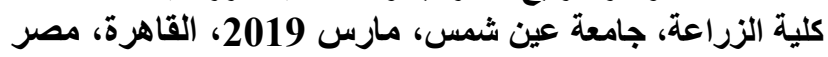

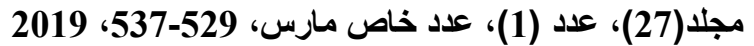

Website: http://strategy-plan.asu.edu.eg/AUJASCl/

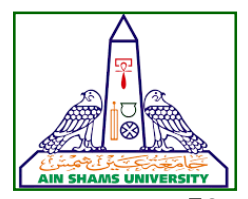

الكثف عن جين الـ MecA في عزلات البكتريا العنقودية المصرية ودراسة السمية

الوراثية الخاصة بهات البكريا

[49]

مروة حسن- سمير عبدالعزيز إبراهيم- أثرف بكري عبدالرازق - سوسن يوسف العتيق

قسم الوراثة- كلية الززاعة- جامعة عين شمس- ص.ب 68- حدائق شبرا 11241 - القاهرة- مصر

*Corresponding author: selateek@agr.asu.edu.eg

Received 25 February, 2019, Accepted 10 March, 2019

مقايسات comet assay ،micronucleus test التي كثفت عن ضرر الحمض النووي بنسبة 22\%-

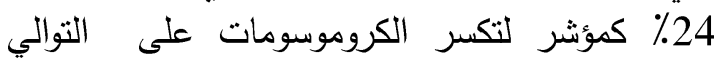

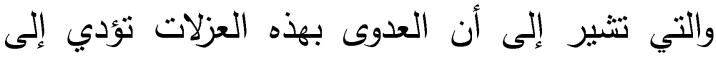

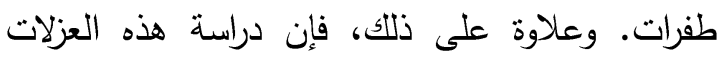
ستعطي فكرة عن ضرورة الاهتمام بنظام مكافحة

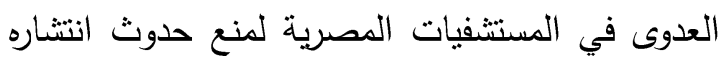
هذا النوع من البكتيريا.

الكلمات الدالة: البكتريا الذهبية العنقودية، جين الـ الذية MecA

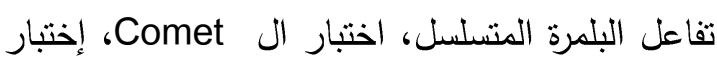
Micronucleus الـ الـ

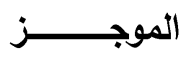

تم جمع خمسون عينة إكلينيكية من مستشفيات جامعة عين شمس خلا الفترة من (مارس- يوليو 2016)، والتي تم تعريفها بإستخدام اختبارات كيميائية

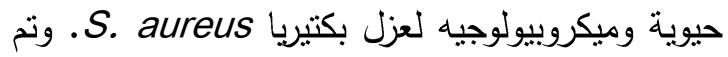
إجراء تفاعل البلمرة المتسلسل باستخدام بادئات محددة لمدرب

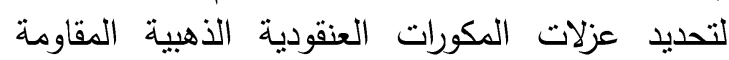
اللميثيسيلين (MRSA) على أساس وجود الجين mec) A. وتم تحديد 68\% من هذه العزلات بأنها MRSA.

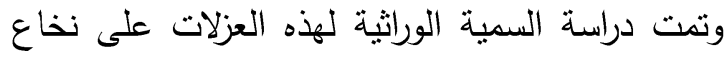

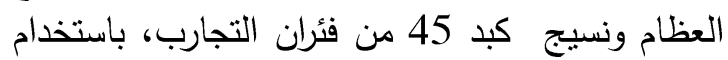

